\title{
АКВАТИЧНА ТОПІКА ВНУТРІШНЬОГО ПЕЙЗАЖУ ДУШІ В ПОЕЗІЇ ПОЛЬСЬКОГО ТА УКРАЇНСЬКОГО РАННЬОГО МОДЕРНІЗМУ
}

\author{
ЯРОСЛАВ НАХЛІК \\ Національний університет „Львівська Політехніка”, Львів - Україна \\ AKWATYCZNA TOPIKA WEWNĘTRZNEGO KRAJOBRAZU DUSZY \\ W POEZJI POLSKIEGO I UKRAIŃSKIEGO WCZESNEGO MODERNIZMU \\ JAROSŁAW NACHLIK \\ Narodowy Uniwersytet „Politechnika Lwowska”, Lwów - Ukraina \\ STRESZCZENIE. W artykule rozpatrywane jest symboliczne ujęcie krajobrazu \\ w modernistycznej poezji jako odzwierciadlenia stanu duszy. Szczególną uwagę skoncentro- \\ wano na toposach akwatycznych. Zbadane zostało funkcjonowanie konwencjonalnego sym- \\ bolu мare tenebrarum w twórczości P. Karmańskiego, A. Langego, S. Przybyszewskiego, \\ L. Staffa. Przeanalizowano wykorzystanie topiki wodnej jako odzwierciadlenia nieświado- \\ mej części psychiki człowieka.
}

\section{AQUATIC TOPIC OF THE SOUL INTERNAL LANDSCAPE IN THE POLISH AND UKRAINIAN POETRY OF EARLY MODERNISM}

\author{
YAROSLAV NAKHLIK \\ Lviv Polytechnic National University, Lviv — Ukraine
}

ABSTRACT. The article deals with a symbolic interpretation of the landscape in modernist poetry as a reflection of the soul condition, with special attention focused on aguatic topik. Also understanding of the conventional symbol mare tenebrarum in the creative works by P. Karmanski, A. Lange, S. Przybyszewski, L. Staff is analyzed. The author explores a water topic using as a reflection of the unconscious part of the human psyche.

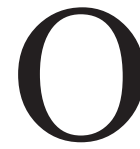

днією 3 визначальних, основоположних рис європейського модернізму $є$ його антиміметична спрямованість. Як слушно зазначає М. Ткачук, „французькі символісти дещо зневажливо відносились до дійсності як „світу явищ”. На їх погляд, у художніх творах потрібно відображати „вищу реальність", тобто те, що лежить за межами можливостей пізнання - трансцендентальне, надпочуттєве, таємницю - первинну ідею, міф"”. П. Ляшкевич також пише про створення нової реальності замість відтворення дійсності як про характерний для модернізму принцип ${ }^{2}$. Досліджуючи поезію представників раннього модернізму, належить постійно пам'ятати про цю іiі особливість, а тому аналізувати образи природи, стихійних явищ, пейзажі, інтер'єри та екстер'єри не як результат мімезису, а як вияв авторської саморефлексії, а подекуди - і катарсису; вираження через образи дійсності емоційних та психічних станів ліричного героя, його сумнівів та страхів. Занадто категоричним c. 40 .

${ }^{1}$ М. Ткачук, Модерністський дискурс лірики та новел Богдана Лепкого, Тернопіль 2005,

${ }^{2}$ П. Ляшкевич, Петро Карманський. Нарис життя і творчості, Львів 1998, с. 10. 
є, однак, зауваження М. Подрази-Квятковської про те, що конструкція молодопольського пейзажу взагалі не має міметичних рис ${ }^{3}$. Варто згадати лише численні вірші про Татри К. Пшерви-Тетмаєра, що, попри безумовно присутній філософський, рефлексійний зміст, є чудовими зразками пейзажної лірики. Митці епохи також активно вживають певну традиційну пейзажну символіку, що передає внутрішній стан душі.

Щодо українського модернізму, то відхід від реалістичного зображення дійсності у творчості поетів Молодої Музи влучно помітив І. Франко, пишучи про П. Карманського: „Автор поневолі кожде явище, кожду життєву згадку підносить на той високий рівень, де щезають буденні дрібниці і відкриваються основні проблеми людського духу й людської етики, контрасти і конфлікти добра і зла, права й обов'язку"4. Зауважмо, однак, що дальше звернення поетів до метафізичного I. Франко засудив, ствердивши, що символізм у їхній творчості переходить у містицизм, у прямування до чогось таємничого, надчуттєвого і неземного.

Порівняння душі з озером чи іншою водоймою, що трапляється, наприклад, у вірші К. Тетмаєра Na królewskim jeziorze, є характерним художнім засобом у поезії раннього модернізму. Воно символізує насамперед глибину, а в ході дальшого семантичного розбору цього символу, за влучним спостереженням М. Подрази-Квятковської, доходимо до важливого слова-ключа - таємниия 5 .

Гніздовим образом усієї акватичної топіки душі є образ mare tenebrarum. Доцільно зацитувати вислів його творця, представника бельгійського символізму М. Метерлінка: „У нашій душі є внутрішнє море, справжнє mare tenebrarum, де бушують дивні бурі... В нашій душі є кімнатка Синьої Бороди, яку не слід відкривати”. Услід за ним С. Пшибишевський стверджує: „Так! За тісним колом свідомих станів нашого Я знаходиться внутрішній океан, море таємниць і загадок, де бушують дивні бурі, там є криївки Сезаму, повні незліченних скарбів і чудес, речей, які не можливо висловити словами"э.

Пишучи про західний модернізм, зокрема про поезію Е. По, якого вважають одним з його натхненників, Г. Башляр зауважує: „У багатьох поетів з'являється також уявне море, яке вмістило в собі Ніч. Це Море Темряви - Mare tenebrarum, де давні мореплавці помістили радше свій страх, ніж досвід"в. Терміном мare tenebrarum на старих картах позначали невідомі морські простори, недосліджені води. Саме в такому значенні він і вживається у внутрішніх пейзажах модернізму — це незвіданий простір людської душі, темрява якого вказує, з одного боку, на можливість будь-яких інтерпретацій, а з другого, — на страх ліричного героя перед невідомістю позасвідомого.

Хронологічно першими цей образ почали використовувати представники Молодої Польщі. Політ звільненої від тіла душі-духа над чорним морем символізує в поезії А. Лянге трагедію людського існування — людина, що прагне

${ }^{3}$ M. Podraza-Kwiatkowska, Symbolizm i symbolika w poezji Młodej Polski: teoria i praktyka, Kraków 1975, s. 107.

${ }^{4}$ I. Франко, Карманський. Ой люлі смутку : Ліричні поезії. Львів, 1906, 8, стор. 80, [в:] його ж, Зібр. творів, у 50 тт., Київ 1982, т. 37, с. 138.

${ }^{5}$ M. Podraza-Kwiatkowska, Symbolizm i symbolika w poezji Młodej Polski: teoria i praktyka, Kraków 1975, s. 171.

${ }^{6}$ M. Ma eterlinck, Confession de poete, cyt. wg Miriam, Wybór pism dramatycznych Maeterlincka, Warszawa 1984, s. XLVII.

${ }^{7}$ S. Przybyszewski, O „nowa” sztukę, [w:] “Życie”, Kraków, 1899, nr 6, s. 102.

${ }^{8}$ G. Bachelard, L'Eau et les reves, Patrz: A. Czabanowska, Wyobraźnia akwatyczna w poezji Młodej Polski, [w:] Pamiętnik Literacki, 1987, z. 3, s. 107. 
поєднання з трансцендентним, приречена на сліпе блукання. Мотив позбавленого сенсу блукання часто втілюється в поезії раннього модернізму, є своєрідним розвитком образу пустки, трагізм якого поглиблюється через активну модальність ліричного героя, перманентний пошук, що приходить на зміну пасивному спогляданню. Таким чином, митці раннього модернізму актуалізують міфологему вічного блукача-Агасфера, яку в українському фольклорі втілює Марко Проклятий, що його запровадив у літературну традицію М. Стороженко. Проте якщо для класичних образів вічних блукачів характерна тяжка провина, гріх, що стають причиною їхньої неприкаяності, то для поетів зламу століть такою причиною є сама світобудова, а не діяльність людини. Блукач раннього модернізму шукає не прощення від Бога, а самого Бога, опору для свого існування.

Політ без мети є квінтесенцією такого блукання, адже політ сам по собі $\epsilon$ символом свободи, звільнення від тілесних пут і земних обмежень. Перетворення ж його на вічний політ-пошук підсилює трагізм становища людини, стає остаточним виразником песимістичної візії світобудови.

W morzu ciemności duch mój toczy się bez końca

Po czarnych jakichś falach, spienionych w kędziory [...]

I duch mój w czarnej nocy wije się tumanach [...]

Sam mieczem archanioła wypędzam swą duszę

Z Edenów - i tak błądzę, z Edenów wygnany ${ }^{9}$.

Двоїстість душі ліричного героя, котрого виганяють з раю і котрий сам виганяє свою душу, пояснюється характерним для модернізму поняттям Світової Душі. Людина у світогляді А. Лянге є еманацією Божества, його невіддільною частиною, а відповідно - ним самим. Нагадаємо, що процес створення світу як еманації характерний для античної міфології і відсутній у християнстві. Непевність, характерна для раннього модернізму, виражена в цьому творі через образ туману.

Над морем „дух літає” і в поезії українських модерністів:

В. Пачовський: „А над море вилітає / Вдаль задивлений мій дух!”10;

П. Карманський: „Зоре! Чом так гаснеш скоро? / Хто ж то прояснить / Вічності незнане море, / Де мій дух летить?"11.

У поезії П. Карманського море набуває абсолютних рис, стає символом вічності, певним типом позачасового буття. Слід також згадати, що П. Карманський є автором автобіографічного циклу Mare Tenebrarum, що дає змогу говорити про його активну рецепцію цього образу.

Можна, звісно, пояснити часте вживання цього образу загальною модою модернізму на символи темного та непізнаваного, однак уважаємо, що темне море є своєрідним словом-ключем епохи, виразником її розуміння топосу душі, i саме цим найпереконливіше можна пояснити його часте вживання в поезії Молодої Польщі та Молодої Музи.

Образ моря може також уживатися самостійно, окремо від образу моря темряви. Наприклад, у П. Карманського:

Затлілись ясні зорі,

Бринить вечірній рій,

Душа купаєсь в морі

Розкішних мрій-надій ${ }^{12}$.

\footnotetext{
${ }^{9}$ A. Lange, Wiersze wybrane, Kraków 2003, s. 73.

${ }^{10}$ В. Пачовський, На стоиі гір, Львів 1907, с. 31.

${ }^{11}$ П. Карманський, 3 теки самоубийия, Львів 1899, с. 41.

${ }^{12}$ П. Карманський, Ойлюлі, смутку, Львів 1906, с. 57.
} 
Образ моря як вияв характерного для раннього модернізму (особливо українського) захоплення екзотичним має позитивне значення звільнення від буденності, символізує втечу ліричного героя від насущних проблем. Недаремно нірвана в поезії раннього модернізму найчастіше передається у вигляді занурення, втечі від зорових та слухових відчуттів, що найлегше передати через пірнання під воду.

Образ води загалом використовується в ранньому модернізмі і як чинник медитативних рефлексій ліричного героя. У цьому плані знаковими є два твори: Над каламутною водою Стефана Чарнецького та Ненаситність Леопольда Стаффа.

Над каламутною водою

Стою в задумі,

Уся моя душа, здається,

Втонула в шумі. ${ }^{13}$

Якщо С. Чарнецький, використовуючи образ потоку, передає стан так званої моментальної нірвани ліричного героя, тимчасового почуття „занурення душі" в шум води, що символізує єдність 3 усім сущим, переживання ведійської формули тат твам асі, то Л. Стафф використовує образ водойми як символ єдиної світової душі. Душу в цьому разі належить ототожнити зі свідомістю людини, що в хвилини задуми звертається до власних потаємних глибин. Ліричний герой бачить у спокійній воді озера не відбиття реального світу, а ідею, що $є$ праобразом неба і землі. Вода як стихія відповідно є втіленням трансцендентного, своєрідним вмістилищем ідеального:

Niczego dosyć duszy mej. Wieczorem

Lubi śnić cicho nad górskim jeziorem,

Oczy i serce topiąc w głąb, co drzemie.

I błogosławi cię, wodo spokojna,

Żeś taka dobra i tak bosko hojna,

Bo w sobie niebo podwajasz i ziemię. ${ }^{14}$

Як слушно зазначає Е. Волощук, тема відображення неба у свічаді моря загалом характерна для творчості молодомузівців - й Б. Лепкого, й П. Карманського, й В. Пачовського. ${ }^{15}$

Модерністи часто вживають також образ човна, що пливе по водному плесу, як символу людського життя. П. Карманський пише у вірші, що дав назву цілій збірці:

Пливем по морі тьми човнами горя й скрути,

Як сіра тінь імли, що йде безкраєм піль,

За нами, гей опир, несеться змора смути

I кличе: Bсе пусте - святий лиш людський біль... ${ }^{16}$

Життя людини поет трактує в екзистенційному ключі, пишучи про горе й скруту існування. Мариністичний образ плавби човном містить значення зникомості людського існування, його малозначущості в масштабах всесвіту: після людини залишається лише минуща, ледь помітна борозна на воді - наголошується на тимчасовому, обмеженому народженням і смертю бутті окремого індивідуума.

Образ моря темряви символізує тут непізнаність законів буття, мізерність людини у світі, повертає читача від антропоцентризму до середньовічної концепції людини як пороху буття. Водночас митець у передчутті світової війни закликає до гуманізму, вказує на цінність людини, іiі переживань.

${ }^{13}$ L. Staff, Poezje zebrane, Warszawa 1967, s. 17.

${ }^{14}$ Tamże, s. 750.

${ }^{15}$ Е. Волощук, Поетична Мариністика Василя Пачовського (збірка „На стоиі гір”), [в:] Василь Пачовський у контексті історії та культури Украйни, Ужгород 2001, с. 81.

${ }^{16}$ П. Карманський, Пливем по морі тьми, Львів 1909, с. 7. 
Б. Лесьмян суголосно використовує образ човна на воді, пояснюючи філософську концепцію А. Бергсона у статті Роздуми про Бергсона: „За Бергсоном, людина це тимчасова борозна, котру залишає човен духа на морі матеріі”' ${ }^{\prime 1}$. Далі митець розвиває цю думку, наводячи власні роздуми: „Людина це слід від удару творчого духа в матерію, це постійна потуга і спротив, буття і небуття"18. Поет відкидає субстанційність людини - вона лише слід, результат взаємодії двох субстанцій-коренів буття. Але водночас будь-що живе $є$ вершиною буття, тілесно-духовим поєднанням. Такий підхід до проблеми людської екзистенції простежуємо і в топіці душі раннього модернізму. Кожна людина - постійний рух, перманентна можливість. Буття людини - не стан, а процес.

Більш детально мотив мандрівки, блукання, мізерності людини та ії поривів, детермінізму існування опрацьовує Т. Міцінський, використовуючи образ оніричної дійсності. Впадає в око характерний політ душі над морем, проте якщо в інших прикладах душа чи дух виступали персоніфікованими образами, то тут поет порівнює душу з променем, акцентуючи увагу на їі нематеріальній природі:

Na szafirowej snów głębinie

toną żałobne gwiazd mych łodzie.

A cień olbrzymi jest na wodzie

Od chmury, która za mną płynie. [...]

Dusza jak płomień biały

Przez morza leci w dal. ${ }^{19}$

Образ променя актуалізує також трансцендентне походження душі, адже проміння світла традиційно вважають символом божественного, його невід'ємним атрибутом.

Останнім акватичним образом, пов'язаним з топосом душі, $є$ фактично видозміна вже проаналізованих образів безодні та прірви душі, що часто моделюються в поезії Молодої Польщі, — це образ потаємної глибини душі. Наведений нижче уривок репрезентує заперечення ідей I. Канта, який вважав зоряне небо (механіку небесних сфер) і моральний закон у людській душі (етичну самосвідомість) основами буття всесвіту. Якщо І. Кант називав найглибшою сутністю людини моральний закон, то модернізм відкрив незвідані й темні простори позавідомого, назвавши несвідоме під впливом дарвінізму цариною тваринних інстинктів (пізніше ще далі цим шляхом піде 3. Фройд). Л. Стафф трактує людську душу як незвідану, найбільшу загадку світобудови. Не лише навколишній світ стає „річчю у собі”, а й сама людина, суб’єкт пізнання, натикається на неможливість осягнути сутність самої себе - саме в цьому полягає основна трагедія мислячої особистості, тут убачаємо корінь модерністського екзистенційного розпачу:

O, gwiazd źrenice

Patrzące w duszy toń! ${ }^{20}$

В іншому вірші поет акватизує образ потаємних глибин душі:

Mrok kocha dusza... W tajń upowita,

Skarby swe skrywa przed blaskiem ranka... [...]

Najgłębsza woda jest zawsze cicha, Najcichsza woda — zawsze głębiną... ${ }^{21}$

\footnotetext{
${ }^{17}$ S. Borzym, Bergson a przemiany światopogladowe w Polsce, Warszawa 1984, s. 185.

${ }^{18}$ Tamże.

${ }^{19}$ T. Miciński, Poezje, Kraków 1984, s. 41.

${ }^{20}$ L. Staff, Poezje zebrane, Warszawa 1967, s. 404.

${ }^{21}$ Tamże, s. 348.
} 
Трактування душі як вмістилища недосяжної таємниці в ранньому модернізмі мотивовано насамперед здобутками тогочасної психології та парапсихології. Насамперед варто згадати концепцію К. Дюпреля, який дійшов висновку, що половини людської сутності (iї свідоме та несвідоме, наше земне обличчя й трансцендентний суб'єкт) розділені рухомою, здатною до пересування порогом нашої свідомості перепоною. Таким чином, через образи темного моря в поезії раннього модернізму артикулюється трагічне становище людини, яка, будучи неспроможною повністю пізнати власну душу, з одного боку, приречена на постійне блукання манівцями в пошуках сенсу свого існування, а 3 іншого, - залежна від несвідомих порухів, а часом, на чому особливо наголошував С. Пшибишевський (концепція „оголеної душі”), — од звірячих інстинктів.

Отож, розбудова в поезії раннього модернізму акватичних образів найчастіше зводилася до активного використання метерлінківського „моря темряви”, через яке передавалися як негативне сприйняття довкілля, спричинене самотністю та розгубленістю в ньому, так і страх та сум'яття перед незнаним потенціалом власного позасвідомого. Молодопольський внутрішній пейзаж в акватичному варіанті виступав у двох найважливіших видозмінах: як статичний образ - відповідник „стану душі”, і як сукупність уявлень, пов’язаних 3 дослідженням позасвідомості. У цьому (другому) випадку це найчастіше було видіння спуску в глибини води, що набувала значення „моря мороку”. I в першому, і в другому випадках поряд з образом моря виникає топос душі, яка трактується як персоніфікація ліричного героя перед лицем безмежного світу, або сама стає темним морем непізнаності і таємниці, що приховує доступ до трансцендентного.

Важливо відзначити й використання образу моря й душі в позитивному ключі — як звільнення від буденності, синоніму втечі в нірвану. У цьому разі спостерігаємо тяжіння поезії раннього модернізму до екзотизму. Описи, де згадано конкретні топоніми, стосуються не близьких географічно Чорного чи Балтійського морів, що було би звичним i, здавалося б, логічним для українських та польських митців, а водойм віддалених, екзотичних - Середземного, Адріатичного та Егейського морів. Навіть у випадку П. Карманського використання цих топонімів зумовлено не лише особистими подорожами, а й поетовим прагненням відірвати українську поезію від народницької буденності завдяки змалюванню далеких країн.

Як бачимо, внутрішній пейзаж душі в польській та українській поезії раннього модернізму доволі часто стає виразником невпевненості та розгубленості ліричного героя. У К. Тетмаєра та П. Карманського, як найяскравіших представників декадентських настроїв, пустка, безодня, сум і темрява душі стають виразниками й загальнолюдського сум'яття епохи, й власних сумнівів та пошуків. Такий підхід до внутрішнього світу людини міг бути викликаний:

- постпозитивістським, декадентським розчаруванням у пізнаваності світу, зневірою в здатності людського розуму до всепізнання;

- $\quad$ відчуттям самотності у світі.

К. Тетмаєр пише про таке світовідчуття, вживаючи акватичний образ „океану смутку", в якому тоне душа:

Czasem nagle uczuwam naokoło siebie

taką straszną samotność, że wzrok kryję w dłonie, 
by nie widzieć tej pustki na ziemi, na niebie,

a w oceanie smutku dusza moja tonie. ${ }^{22}$

- певною модою на західноєвропейське модерністське кліше „море темряви". Зазначимо, що одна з ліричних збірок П. Карманського називається Пливем по морі тьми, також поет створив вже згадуваний поетичний цикл Mare tenebrarum;

- новими знаннями про природу позасвідомого, трактування людини як поєднання світлих і темних сил. Ще одним виявом підходу митців раннього модернізму до розуміння внутрішнього світу людини є вжите у Л. Стаффа поняття підземелля душі:

[...] i wejdź w podziemie duszy, gdzie śpią twe rozpacze ${ }^{23}$.

Найважливішим здобутком використання засобів внутрішнього пейзажу вважаємо перехід від описово-лозунгової масової поезії доби позитивізму до інтимно-суб'єктивної, а водночас глибоко філософської поезії, хоча й обумовленої певними загальними конвенціями епохи. Щодо українського раннього модернізму, то М. Бондар слушно вказує на те, що безсумнівним внеском Молодої Музи в українську поезію стала нова потужна активізація суб’єктивного первня, легітимізація „приватних” переживань, інтерес до внутрішніх (іноді глибинних) станів особистості, зокрема страждань, настроїв туги, розчарування ${ }^{24}$. Дослідник польського модернізму В. Гутовський також зазначає, що модерністи підкреслювали дезінтеграцію традиційної особистості, відмінність глибокого Я (душі) стосовно свідомого Я, заохочували до подорожі через mare tenebrarum позасвідомого до таємничих країн ${ }^{25}$.

У польській та українській поезії раннього модернізму поряд із вживанням топосу душі активно використовується засіб внутрішнього пейзажу. Безсумнівно, в такому трактуванні душа є символом внутрішнього світу людини. У поезії моделюються як відкриті топоси - озеро, море, океан, безодня, так і закриті - каплиця, храм, замок, ліс, при цьому внутрішній пейзаж є своєрідним мистецьким утіленням метафори-антиномії А. Шопенгауера про людинувазу, яка не лише є частиною світу, а водночас містить всесвіт у собі.

${ }^{22}$ K. Przerwa-Tetmajer, Poezje, Warszawa 1980, s. 292.

${ }^{23}$ L. Staff, Poezje zebrane, Warszawa 1967, s. 78.

${ }^{24}$ М. Бондар, „Молода Муза” й модернізм в украӥнській поезії, [в:] „,Молода Муза” і літературний прочес кіния ХІХ-початку ХХ століття в Украйні і Свропі, Львів 1992, с. 13.

${ }^{25}$ W. Gutowski, Mit, eros, sacrum: sytuacje młodopolskie, Bydgoszcz 1999, s. 31. 